\title{
Ecology as One of the Factors of Sustainable Development
}

\author{
A. I. Beksultanova ${ }^{1, *}$, S. K. Shardan ${ }^{2}$, N. N. Ivanskaya ${ }^{3}$ \\ ${ }^{1}$ Chechen State University named after A.A. Kadyrov, Grozny, Russia \\ ${ }^{2}$ North Caucasian State Academy, Cherkessk, Russia \\ ${ }^{3}$ Ulyanovsk Civil Aviation Institute, Ulyanovsk, Russia \\ *Corresponding author. Email: adamovaaybika@mail.ru
}

\begin{abstract}
Today, in the context of the COVID-19 pandemic, the sustainable development agenda has come into focus from a new angle. The issues of inequality, as well as the topics of transparency, effective interaction of various stakeholders to overcome common global challenges, on the other hand, are becoming more and more relevant. Environmental problems affect all countries, and many of them - such as climate warming or pollution of the world's oceans - are global in nature. Because of them, the health of the population is deteriorating, ecosystems are disrupted, states are suffering financial losses. Governments are implementing multi-billion dollar programs to prevent or minimize environmental damage. According to the UN, key global environmental problems include climate warming, depletion of the ozone layer, accumulation of waste (including toxic ones), deforestation, loss of biological species, water and air pollution. The paper assesses the current state of the environmental sphere, state policy and investors' plans for its development, considers the industries that make the main contribution to environmental pollution, and their investments in the environment.
\end{abstract}

Keywords: Sustainable development, ecology, sustainability.

\section{INTRODUCTION}

All countries of the world to one degree or another suffer from global and local environmental problems. They are solved by supranational institutions such as the UN and its subordinate structures, national governments, non-profit organizations, as well as private companies. For the most part, investments in green initiatives are irreversible. However, there are projects that not only benefit the environment, but also allow you to make money on them. They are launched, including in the formats of public-private partnerships.

In recent times due to the ongoing changes in the economy on global scale affects all components of local economies around the World [11].

Interestingly, the COVID-19 pandemic, with its detrimental impact on the economy, had a rather positive impact on the environment. According to the IEA, in the first quarter of 2020, global energy demand fell by $3.8 \%$ compared to the same period in 2019, which- reduced carbon dioxide emissions by $5 \%$. Demand for coal $(8 \%)$ and oil $(5 \%)$ declined the most, and if the global lockdown had lasted until the end of the year, they would have fallen by $8 \%$ and $9 \%$, respectively, in 12 months. The demand for other resources, with the exception of renewable energy sources, would also fall - for them it could grow by almost $1 \%$. Over the past 30 years, energy consumption and carbon dioxide emissions from it have been continuously growing (from 1990 to 2018, according to the IEA, coal consumption increased by $33 \%$, oil and petroleum products - by $15 \%$ and $56 \%$, gas - by $71 \%$, and carbon dioxide emissions from them - by $63 \%$ ), so such a drop can be considered significant (although in general, a lockdown is unlikely to affect the "purity" of the atmosphere on a global scale). And the small growth in renewable energy against this background is another evidence of the "greening" of the world economy. [1]

The issues of global sustainable development are attracting more and more attention of the world community and international organizations, they are recorded in the documents of the OECD, IMF, World Bank, WTO and in the reports of corporations. [10]

Plans for solving global problems related to the environment and sustainable development in general are recorded in a number of international documents. 
The vector in this area is set by the final document of the 2012 UN Conference on Sustainable Development - "The Future we want", as well as the 2030 Agenda for Sustainable Development and the Paris Climate Agreement, adopted by the UN in 2015. At the same time, the Paris agreement was signed by Russia in 2016-, and will enter into force for all countries in 2021-.

"The future we want" defines the concept of sustainable development as a priority of the twenty-first century, and lays in its foundation the "green" economy. The sustainable development agenda is developing this idea.

The participating countries, including Russia, have pledged to implement 17 Sustainable Development Goals (SDGs), which are aimed at improving the wellbeing of the world's population and protecting it. These include the creation of basic infrastructure; availability and rational use of clean water; universal access to affordable, reliable, sustainable energy sources; safety and environmental sustainability of cities; rational consumption (food, energy, etc.); combating climate warming; conservation of marine and terrestrial ecosystems and others.

The Sustainable Development Agenda sets 17 SDGs and 169 targets for them. To assess progress in achieving them, over 230 indicators have been developed, and each of the 192 countries that signed the document must submit at least two voluntary reports in this field by 2030 .

Among the main topics considered in studies on environmental and natural factors, one can note an increase in the average annual temperature on the planet, a change in the regime of precipitation and distribution of precipitation, floods and droughts; coastal erosion; rise in the level of seas and rivers; landslides, rockfalls and avalanches; contamination of accessible sources of clean drinking water; change in soil fertility. Among the main effects of these factors are economic damage from extreme weather events; the spread of vector-borne diseases; impact on human health; climatic migration; depletion of natural resources, etc. [2] Most of them formed the basis for the 17 UN Sustainable Development Goals (SDGs) for the period up to 2030 [3]

The main goal of the Paris agreement is to prevent the temperature on the planet from rising by more than 2 degrees by 2100 from the average level of 1850-1900 (now the temperature is higher by 0.75 degrees). For this, countries must implement national plans and strategies to reduce emissions of pollutants, introduce "green" technologies, transition to a carbon-free economy, and others. [4]

In recent decades, the problems of climate warming, depletion of the ozone layer, environmental pollution due to- large amounts of waste, deforestation and others have become more acute on the planet. One of the key documents at the international level that contributes to their solution is the concept of sustainable development, adopted by the UN in 2015. Russia assumed obligations under this and other similar acts, but so far it has made a modest contribution to solving global problems: this is evidenced by its statistics on carbon dioxide emissions, waste production and other indicators.

\section{RESEARCH METHODOLOGY}

The paper contains the results identified in the framework of published reports and analytical materials of international organizations, specialized analytical publications, data from foreign and Russian news agencies, as well as interviews and articles by leading analysts and experts. The methods of the research performed contain theoretical and empirical parts, methods of description and are supported by graphical methods of illustrating the data.

\section{RESEARCH RESULTS}

Among the main sources of environmental pollution are enterprises operating in the mining and manufacturing industries and energy. However, they are trying to compensate for this by investing in environmental protection and rational use of natural resources (see Figure 1). According to our calculations, the largest Russian oil and gas companies (with revenues of 0.35 trillion rubles for 2018) have spent more than 1 trillion rubles on "green" infrastructure and environmental initiatives over the past five years, of which about half are investments in fixed assets. In 2019 alone, Gazprom, Lukoil, Rosneft and Surgutneftegaz invested over 180 billion rubles in environmental protection and rational use of natural resources. Less, but also significant environmental costs for mining companies. According to our estimates, in 2015-2019, the ten largest enterprises (with annual revenues of 0.3 trillion rubles) amounted to slightly less than 0.4 trillion rubles, including about 80 billion rubles in 2019. Large energy enterprises spend even less. For example, in 2019, Rosseti spent 0.6 billion rubles on environmental protection, Inter RAO - 1.3 billion rubles, and RusHydro - 1.9 billion rubles. At the same time, the total revenue of these three companies in 2018 reached almost 0.8 trillion rubles.

Let's consider the industries that are the main contributors to environmental pollution and their investments in the environment.

The data in Figures 1, 2, 3 on emissions of pollutants into the atmosphere from stationary and mobile sources, production and consumption waste generation and discharge of polluted wastewater, as well as investments in fixed assets and current expenditures of enterprises in 
the field of environmental management and environmental protection for 2018 are given. [5]

Thus, the real costs of environmental protection in Russia have not increased since 2015. And industrial companies that cause huge damage to nature (see Figures $1,2,3$ ) are ready to spend only a small part of their funds on its protection and restoration. The measures taken by companies are not enough to combat this. For example, Russia's greenhouse gas emissions are among the highest in the world, which- is why it is still among the outsiders in compliance with the terms of the Paris agreement [6]

It is still difficult to say how much environmental assistance from private companies will be able to outweigh the harm from them in the coming years. Against the background of the pandemic crisis-, both scenarios look plausible: both the fact that companies will rethink the approach to environmental protection towards the growth of "green" investments, and the fact that financial difficulties due to- the crisis will not allow

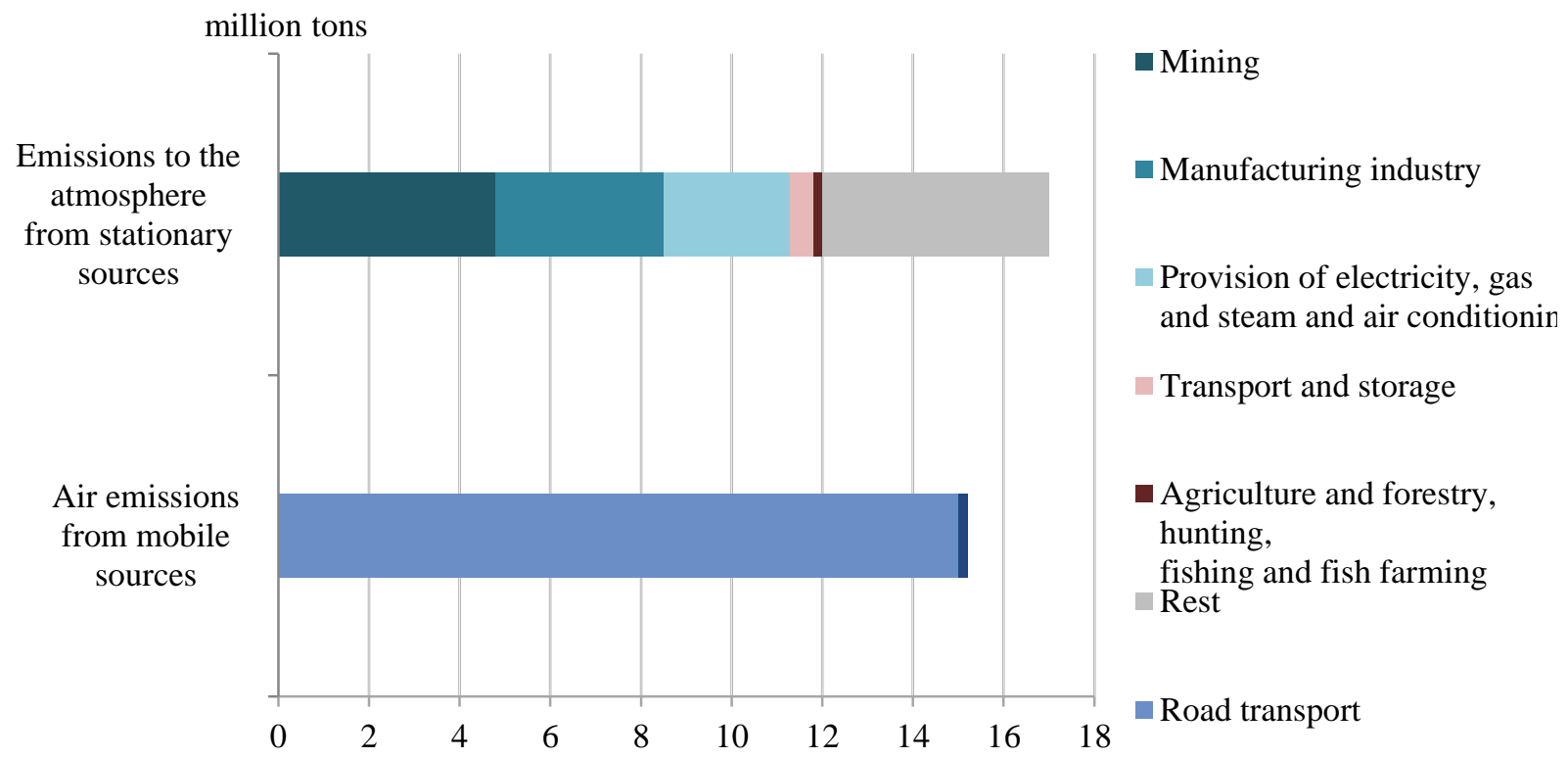

Figure 1 Emissions of pollutants into the atmosphere from mobile and stationary sources in 2018

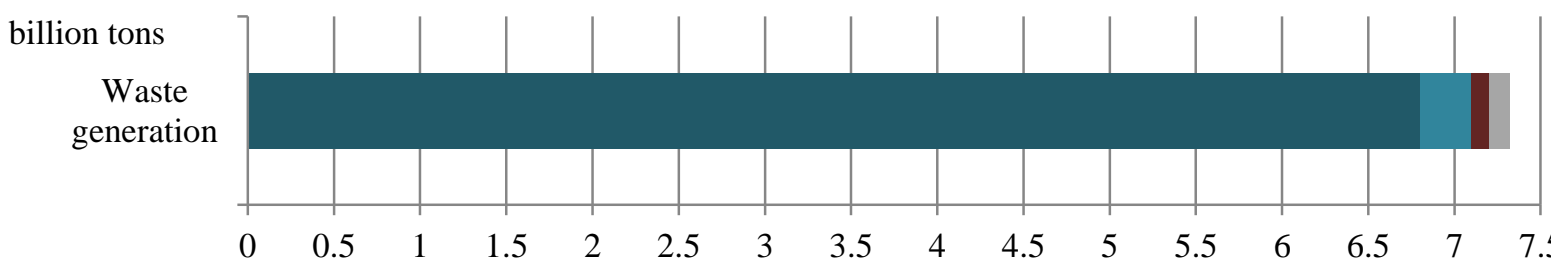

Figure 2 Discharge of contaminated wastewater and the formation of production and consumption waste in 2018

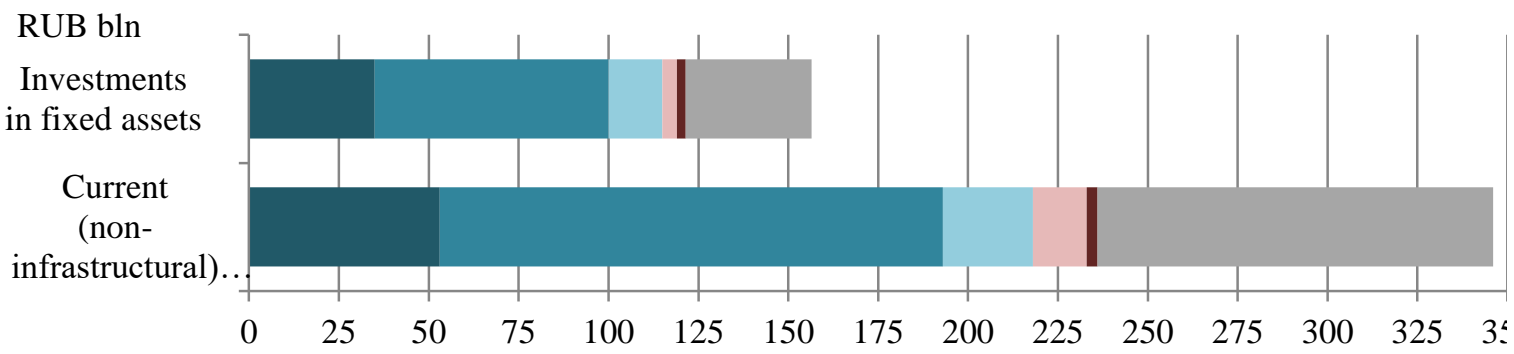

Figure 3 Expenditures on environmental protection and environmental management 
companies to expand their environmental projects. At the same time, we expect that private investments in the environment will grow in the medium and long term.

There are several main channels for spending money on the environment in the federal budget. These are the state programs "Environmental Protection", "Reproduction and Use of Natural Resources" and "Development of Forestry". Since 2019, they overlap with the national project "Ecology", adopted according to the decree of May 2018. In addition, in the context of sustainable development, the state program "Energy Development" is important. According to specialists' calculations, over the past five years, the total government spending on state programs supervised by the Ministry of Natural Resources has ranged from 106 to 134 billion rubles. in year. In total, over 10 years from 2015 to 2024 - they account for $60 \%$ of program budgets. At the same time, some areas do not relate to ecology and the development of a "green" economy or affect them indirectly.

The national project "Ecology" is the "greenest" strategic planning document, however, this project had an insignificant impact on the introduction of innovations into the existing state programs. Its main achievement is to increase environmental costs: in comparison with the previous year, in 2020 alone, they should grow by almost $30 \%$. In addition, thanks to the national project, the environmental aspects of various state programs were combined in one document: for the development of utilities, industry, and the nuclear energy complex.
According to some calculations of experts, the government is less efficient in assimilating funds under the "green" articles of the federal budget than in other areas of spending. On average, in 2015-2019, 92.5\% of the planned funds were spent within the framework of state programs for environmental protection, reproduction and use of natural resources and forestry development, which is 4.7 percentage points less than the development of the entire federal budget. For three quarters of 2020, expenditures on these programs amounted to 104.3 billion rubles, or $58.3 \%$ of the approved funds (see Figure 4) - 6 p.p. below the federal budget execution [7]

The budget utilization for the profile national project is even lower than for the state programs. In 2019 - the first year of the implementation of the May decree "Ecology" became the last of the 13- national projects in terms of execution. According to our calculations based on Treasury data, 36.9 billion rubles were spent on it out of the planned 55.6 billion rubles, or only $66.3 \%$ (see Figure 10). The funds were fully spent only on two of the 11 - federal projects - "Clean Air" (2.9 billion rubles) and "Infrastructure for waste management of hazard classes I-II" ( 0.2 billion rubles). Less than half of the approved money went to the "Conservation of biological diversity and the development of ecotourism" ( 0.18 out of 0.59 billion rubles) and the "Integrated system for the management of MSW" ( 0.6 out of 11.4 billion rubles), and to "Implementation of the best available technologies "was not spent in any of the planned 0.3 billion rubles. Over the nine months of

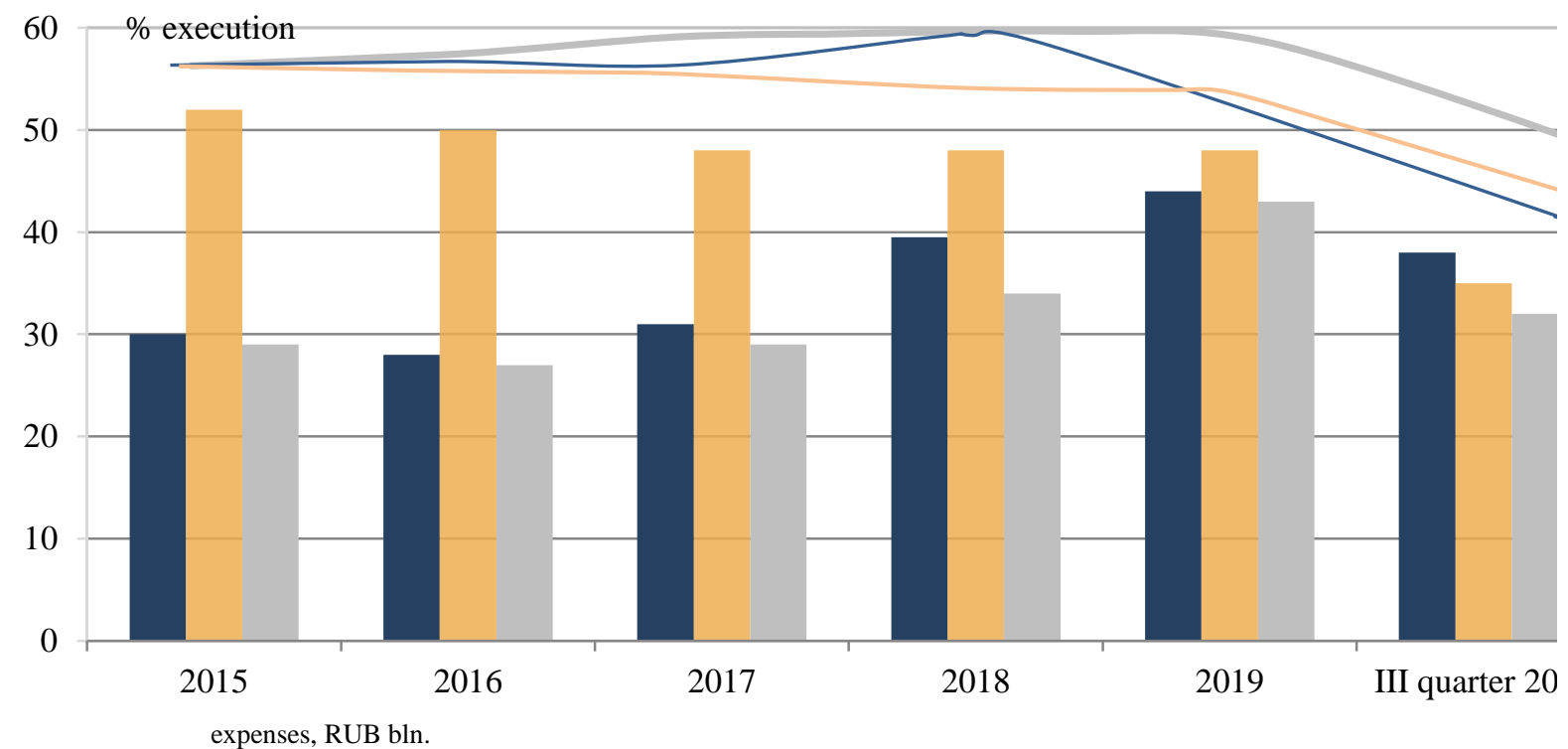

$\square$ Environmental protection
$\square$ Reproduction and use of natural resources
$\square$ Forestry development

Figure 4 Execution of the federal budget for "green" state programs 
2020, the situation has hardly changed. The use of funds for "Ecology" reached only 30.4 billion rubles, or $42.2 \%$. According to this indicator, it is in the penultimate place among national projects: the situation with the Digital Economy is worse, for which only $20.6 \%$ of the approved money was brought in.

\section{RESULT DISCUSSION}

According to specialists' calculations, in 2020 the total planned expenditures of the Russian government on "green" state programs and federal projects will be almost 200 billion rubles, and without taking into account measures not directly related to environmental protection - about 130 billion rubles. The total environmental investments of the state and business in 2019, according to Rosstat, exceeded 870 billion rubles. In our opinion, this is not enough, given the scale of environmental problems and the high cost of solving them.

Russia's need for investments only in some projects related to the environment reaches 5.9-7 trillion rubles in the future until 2024. This assessment included minimal landscaping and landscaping, the creation of infrastructure for the processing of household waste, bringing the share of renewable energy to $4-5 \%$ of the total generation, the renewal and development of urban public transport, as well as the minimum necessary measures in the field of restoration and environmental protection. In part, this amount will be covered by budgetary investments in existing programs, but without the participation of business, "greening" the economy is impossible.

Only a few companies on the Russian market are ready to invest in environmental protection measures, and those that are ready spend a small share of their funds on this. Most of the "green" business investments belong to a small circle of companies (mainly industrial), at the same time causing the greatest harm to the environment: in 2019, the 15 largest of them spent about 0.3 trillion rubles on the environment - this is almost a third of total expenditures of the country and the private sector for the whole year. But on average, the costs of such companies did not exceed $1 \%$ of their revenue.

Often, companies that position themselves as green, follow the principles of sustainable development, invest in environmental protection to increase their productivity, the ability to gain access to new markets and within the framework of GR and PR campaigns. However, even in the case, the benefits of green investments are significant. In the future, the number of "responsible" companies, in our opinion, will grow, although the crisis may slow down this process.

In general, the desire for socially significant spending is more typical for the state than for private companies. The latter are more willing to invest in costeffective green initiatives. We believe these are possible in the areas of renewable energy, waste management, public transport, urban landscaping and greening, ecotourism, as well as - but slightly less - in the field of water and air purification, restoration of biodiversity, "green" construction. Moreover, they can be launched both entirely at private expense, and within the framework of concessions and PPPs.

In our opinion, in Russia the concession format is mainly relevant in the field of waste management among all areas that are related to the environment. According to experts, at the end of November 2020, 38 such initiatives totaling 45.7 billion rubles were launched in the segment of 100 million rubles in the country. And in the next year or two, at least 17 more units worth 36.2 billion rubles have a high chance of launching. Also, projects in other industries have a high potential for launching within the framework of PPP, but they are not so popular in the infrastructure market. For example, we are talking about alternative energy only one such concession agreement has been signed in the Russian Federation - or public transport, where the practice of launching concessions is greater, but the potential of the niche remains "undisclosed".

Globally, the implementation of environmental infrastructure projects is supported by green finance instruments. They are used both within the framework of PPPs and when launching corporate projects. These include securitized securities, green bonds, green loans, and sovereign green bonds. The potential of the issue of the latter in our country may amount to about 700 billion rubles on the horizon for up to five years.

\section{CONCLUSION}

The basis of the ecological component of sustainable development is the preservation of the sustainable functioning of the entire ecosphere as a whole, at the level necessary for the realization of the needs of humanity. Since the very possibility of life depends on the integrity of the Earth's ecosystems, the preservation of their ability to heal themselves plays a special role here. In this regard, special attention should be paid to taking into account the maximum loads on ecosystems, because with excessive loads, ecosystems lose their ability to recover and are destroyed.

Environmentally sustainable development involves the organization of life, in which emissions of pollutants should not exceed the assimilation capacity of ecosystems. A special place in the framework of environmentally sustainable development is occupied by the preservation of biodiversity and the quality of environmental components (water, air, soil, etc.) at a level that ensures the safety of human life and health. [8] 
So far, there are only a few green players in the country among funds and banks. Due to the lack of a well-developed legal framework in the field of green financing and regulations on investments in such instruments for long-term investors in Russia, the development of this sector is inactive. At the same time, business is particularly interested in timely "readjust" to responsible financing, otherwise there is a chance to lag behind developed countries and lose the opportunity to attract money in the global financial market due to- noncompliance with environmental standards.

Achieving sustainable economic development on a global scale will require wise use of resources, technology, economic incentives and strategic policy planning at the local and national levels. [9]

\section{REFERENCES}

[1] International Energy Agency, https://www.iea.org/.

[2] G. Safonov, S. Avaliani, A. Dorina, A. Bolotov, M. Safonov, Social Consequences of Climate Change. Building Climate Friendly and Resilient Communities via Transition from Planned to Market Economies. Friedrich-Ebert-Stiftung, 2019.

[3] 2030 Agenda for Sustainable Developmen, UN.

[4] Paris Climate Agreement. Purpose, structure and history of the document. https://tass.ru/info/6917170.

[5] Data from the Ministry of Natural Resources. https://www.mnr.gov.ru/.

[6] InfraOne Research Review: Should We Wait for the Ecology of Private Investments? https://infraone.ru/sites/default/files/analitika/2020/ investicii_v_infrastrukturu_ekologiya_2020_infrao ne_research.pdf.

[7] Treasury data, InfraOne Research analysis and calculations.

[8] Ecology and sustainable development. https://www.sites.google.com/site/kamillasulayman ova/home/nanotehnologia/ekologia-i-ustojcivoerazvitie.

[9] S. Zhiznin, V. Timokhov, Impact of energy on sustainable development. In: World economy and international relations, 61(11) (2017) pp. 34-42. DOI: https://doi.org/10.20542/0131-2227-2017-6111-34-42.

[10] A. Shlikhter, Business strategies of companies in the context of sustainable development. In: World economy and international relations, 64(4) (2020) pp. 37-44. DOI: https://doi.org/10.20542/01312227-2020-64-4-37-44.
[11] M. Szabo, M.S. Csete, T. Palvolgyi, Resilient Regions from Sustainable Development Perspective. In: European Journal of Sustainable Development, 7(1) (2018) pp. 395-411. DOI: https://doi.org/10.14207/ejsd.2018.v7n1p395. 